\title{
Effects of melatonin implants on plasma concentrations of testosterone, thyroxine and prolactin in the male silver fox (Vulpes vulpes)
}

\author{
M. Forsberg and A. Madej
}

Departments of Clinical Chemistry and Obstetrics \& Gynaecology, College of Veterinary Medicine, Swedish University of Agricultural Sciences, P.O. Box 7038, S-750 07 Uppsala, Sweden

\begin{abstract}
Summary. Melatonin administration in the form of slow-release implants advanced breeding activity in silver fox males when treatment began in June. Plasma testosterone concentrations were significantly higher in treated animals than in controls from September to November, whereas in February and March they were significantly lower. Plasma prolactin concentrations were significantly reduced immediately following melatonin treatment in June but increased to greater levels than control values and 'peaked' after 7 months. This 'peak' was associated with a rapid decrease in testosterone secretion. The normal seasonal spring rise in prolactin secretion was prevented by melatonin administration. Thyroxine values decreased and were significantly lower after 2 months of melatonin treatment.
\end{abstract}

Keywords: melatonin; reproduction; silver fox; male; prolactin; thyroxine; testosterone

\section{Introduction}

Survival and successful reproduction in animals are strongly dependent on ability to predict seasonal changes in the environment. The most reliable predictor of the seasons in the temperate and polar regions is the annual changes in daylength. The physiological mechanisms by which changes in daylength regulate hypothalamic-pituitary-gonadal function and dictate the seasonal pattern of hormone secretion (and ultimately fertility) are still poorly understood. There is strong evidence that the pineal gland is involved through its secretion of melatonin (for review, see Arendt, 1986; Reiter, 1987). Recent studies show that melatonin affects hypothalamic dopamine metabolism and alters pituitary responses to dopamine (Steger et al., 1984).

The role of prolactin in the reproductive cycle of the male is unclear. It has been suggested that prolactin may not only enhance the effect of LH on testosterone production but also act synergistically with testosterone to stimulate the growth and secretion of accessory sex organs (Matthews et al., 1978; Zipf et al., 1978). In most seasonally breeding species prolactin presents a clearly defined annual cycle with peak levels in spring and summer. Although the reason why secretion increases in summer is unknown, the hormone is known to have important seasonal effects on the moulting cycle (Allain et al., 1981; Lincoln \& Ebling, 1985). The pineal also appears to mediate the effects of photoperiod on hormonal functions previously not considered directly associated with reproduction. Seasonal fluctuations in thyroid hormones seem to depend on photoperiod and to be involved in the regulation of reproductive function in mink and sheep (Jacquet et al., 1986; Nicholls et al., 1988).

Earlier experiments have shown that the reproductive cycle as well as the moulting cycle of the silver fox (Vulpes vulpes) male can be influenced by changes in photoperiod (Forsberg et al., 1989) and melatonin administration (Connor, 1988; Forsberg et al., 1990). Under natural daylight conditions plasma concentrations of testosterone and thyroxine show distinct seasonal variations 
(Joffre \& Joffre, 1975; Joffre, 1976; Maurel \& Boissin, 1981), and prolactin secretion increases during and after the mating season (Maurel et al., 1984).

The aim of the present study was to determine how long-term melatonin treatment affects the secretion of testosterone, thyroxine and prolactin in the male silver fox.

\section{Materials and Methods}

Animals and experimental design. Ten adult silver fox males were housed individually under natural daylight conditions at the Swedish University of Agricultural Sciences, Uppsala (latitude: $59^{\circ} 50^{\prime} \mathrm{N}$; longitude, $17^{\circ} 50^{\prime} \mathrm{E}$ ) from March 1987 until the end of April 1988. The animals were given water ad libitum and fed a standard ration wet feed. Melatonin implants (Wildlife Laboratories Inc, Fort Collins, Colorado, USA) (10 mg: length $9 \mathrm{~mm}$, width $2 \mathrm{~mm}$, surface area $65 \mathrm{~mm}^{2}$ ) were placed beneath the skin over the left chest wall while the animals were anaesthetized with ketamine $(10 \mathrm{mg} / \mathrm{kg})$ (Ketalar: Parke-Davis, Raritan, NJ, USA; $50 \mathrm{mg} / \mathrm{ml}$ ). Five males were given implants of $40 \mathrm{mg}$ melatonin on 1 June 1987 (when the testes were fully regressed) and again on 4 August and 5 October 1987. All implants remained in place until the end of the experiment. The other 5 males served as controls.

Blood sampling. Blood samples were collected monthly from the cephalic vein between 11:00 and 15:00 h. The animals were sedated with $2 \mathrm{mg}$ acepromazine $/ \mathrm{kg}$ (Plegicil: Agrivet AB, Uppsala, Sweden; $10 \mathrm{mg} / \mathrm{ml}$ ). All blood samples were collected in heparinized tubes. Plasma was immediately centrifuged and stored at $-20^{\circ} \mathrm{C}$ until assayed.

Hormone assays. Plasma concentrations of testosterone, melatonin, thyroxine and prolactin were determined by radioimmunoassays. The assays for testosterone and melatonin have been previously validated for use in the silver fox (Forsberg et al., 1989, 1990).

The intra-assay coefficients of variation for testosterone, calculated from the precision profiles of 5 different assays, were below $13 \%$ in the range of 3.5 to $34.7 \mathrm{nmol} / \mathrm{l}$. The inter-assay coefficients of variation (\%) for quality control samples were $8.6($ mean $=9.2 \mathrm{nmol} / 1, n=13), 8.0($ mean $=17.4 \mathrm{nmol} / 1, n=13)$ and 8.6 (mean $=25.5 \mathrm{nmol} / \mathrm{l}, n=11$ ).

The intra-assay coefficient of variation for the melatonin assay was $20 \%$ at $84 \mathrm{pmol} / 1$ and remained $<15 \%$ for concentrations exceeding $168 \mathrm{pmol} / 1$. The coefficients of variation (\%) for two pooled plasma samples of silver fox origin, estimated in 5 different assays, were $15.5($ mean $=346 \mathrm{pmol} / \mathrm{l})$ and $11.9($ mean $=649 \mathrm{pmol} / \mathrm{l})$.

The system to measure thyroxine in fox plasma utilized ${ }^{125}$ I-labelled L-thyroxine (Du Pont de Nemours \& Co., NEN Research Products, Boston, MA, USA) as tracer, L-thyroxine (Sigma Chemical Company, St Louis, MO, USA) as standard and thyroxine antiserum (Benenden Antisera, RAST Allergy Unit, Cranbrook, UK) at a final dilution of 1: 5000. Thyroxine standards were prepared in charcoal-stripped plasma obtained from hypothyroidic dogs. To inhibit thyroxine binding to plasma proteins 8-anilino-1-naphthalene sulphonic acid was added to standards and samples as described by Larsson \& Lumdsen (1980). After a $2.5 \mathrm{~h}$ incubation at room temperature, $2 \mathrm{ml}$ of a second antibody suspension (Pharmacia AB, Uppsala, Sweden) were added to each tube. After an additional $30 \mathrm{~min}$ at room temperture the tubes were centrifuged at $1500 \mathrm{~g}$ and radioactivity was quantified in a gamma counter (Searle Analytic Inc., IL, USA).

The thyroxine antiserum bound $31 \cdot 0 \%$ (s.d. $=2 \cdot 2, n=50$ ) of the ${ }^{125} \mathrm{I}$-labelled thyroxine, and the standard curve ranged from 2 to $128 \mathrm{nmol} / \mathrm{l}$. Dilutions of silver fox plasma were parallel to the standard curve. The intra-assay coefficients of variation for thyroxine concentrations in the range of 8.2 to $128 \mathrm{nmol} / 1$ were below $10 \%$. The interassay coefficients of variation (\%) for quality control samples, estimated in 50 assays, were $12.4($ mean $=34.4 \mathrm{nmol} / \mathrm{l})$ and 10.3 (mean $=73.5 \mathrm{nmol} / \mathrm{l})$. The slope of the dose-response curve after logit-log transformation was -1.003 (s.d. $=0.067, n=50$ ).

The prolactin assay used an antiserum against dog prolactin (CPRL) (AFP-16111778) at a final dilution of 1:87 500, radioiodinated dog prolactin (AFP-2451B), and dog prolactin (NIADDK cPRL-RP-1, AFP-245IB) as standard (A. F. Parlow, Harbor-UCLA Medical Center, Torrance, CA, USA). Cross-reactivity with dog growth hormone was $0.04 \%$. The iodination (carrier-free ${ }^{125} \mathrm{I}$, Amersham International plc, Amersham, Bucks, UK) was performed by the chloramine-T method (Greenwood et al., 1963), using $7.5 \mu \mathrm{g}$ chloramine-T/2 $\mu \mathrm{g}$ protein and an exposure time of $20 \mathrm{sec}$. Overnight incubation was carried out at room temperature. The separation of free from antibody-bound hormone followed the procedure for thyroxine described above except that $0.5 \mathrm{ml}$ of the second antibody was used.

The antiserum bound $49 \cdot 4 \%$ (s.d. $=5 \cdot 5, n=4)$ of the ${ }^{125} \mathrm{I}$-labelled dog prolactin and the standard curve ranged from 0.05 to $3.2 \mathrm{ng}$. Dilutions of silver fox plasma from $100 \mu \mathrm{l}$ to $12.5 \mu \mathrm{l}$ were parallel to the dog prolactin standard. The sensitivity of the assay, calculated from the precision profile, was $0.02 \mathrm{ng} /$ tube (s.d. $=0.01$ ), corresponding to $0.2 \mu \mathrm{g} / \mathrm{l}$ for $100 \mu \mathrm{l}$ plasma samples. The amount of dog prolactin needed to cause $50 \%$ inhibition was $0.8 \mathrm{ng} / \mathrm{tube}$ (s.d. $=0.1$ ). The intra-assay coefficient of variation for prolactin concentrations in the range of 1.8 to $40.6 \mu \mathrm{g} / \mathrm{l}$ was below $10 \%$. The coefficients of variation $(\%)$ for three pooled plasma samples of silver fox origin, estimated in $3-5$ different assays, were $30.0($ mean $=1.0 \mu \mathrm{g} / \mathrm{l}), 11.3($ mean $=9.7 \mu \mathrm{g} / \mathrm{l})$ and $9.6($ mean $=25.9 \mu \mathrm{g} / \mathrm{l})$. The slope of the dose-response curve in 4 assays was -0.899 (s.d. $=0.012$ ) after logit-log transformation. When known amounts of dog prolactin were added to silver fox plasma the recovery of prolactin averaged $104 \cdot 9 \%(\mathrm{~s} . \mathrm{d} .=13 \cdot 2, n=12)$. Measured concentrations of testosterone, thyroxine and prolactin represent the mean of duplicate determinations, while those of melatonin are based on triplicate determinations. 
Examination of fur. Fur development (maturity, pigmentation) was evaluated in August 1987. Grading was done without the grader knowing which group each animal belonged to.

Statistical methods. Statistical analysis of the data was carried out with the Statgraphics (STSC, Inc., Rockville, MD, USA) statistical package using analysis of variance and the LSD test. All statistical tests having a $P$ value of $<0.05$ were considered significant. Means are expressed as \pm s.e.m.

\section{Results}

\section{Melatonin}

Serum concentrations of melatonin were variable in animals treated with melatonin implants and in their corresponding controls (Fig. la). In the control group melatonin concentrations were significantly elevated from January to April 1988. Mean melatonin values in animals bearing implants were significantly higher than controls between the first implantation in June 1987 and the end of the study (experimental group $917 \pm 56 \mathrm{pmol} / 1$, control group $120 \pm 15 \mathrm{pmol} / \mathrm{l}$ ).
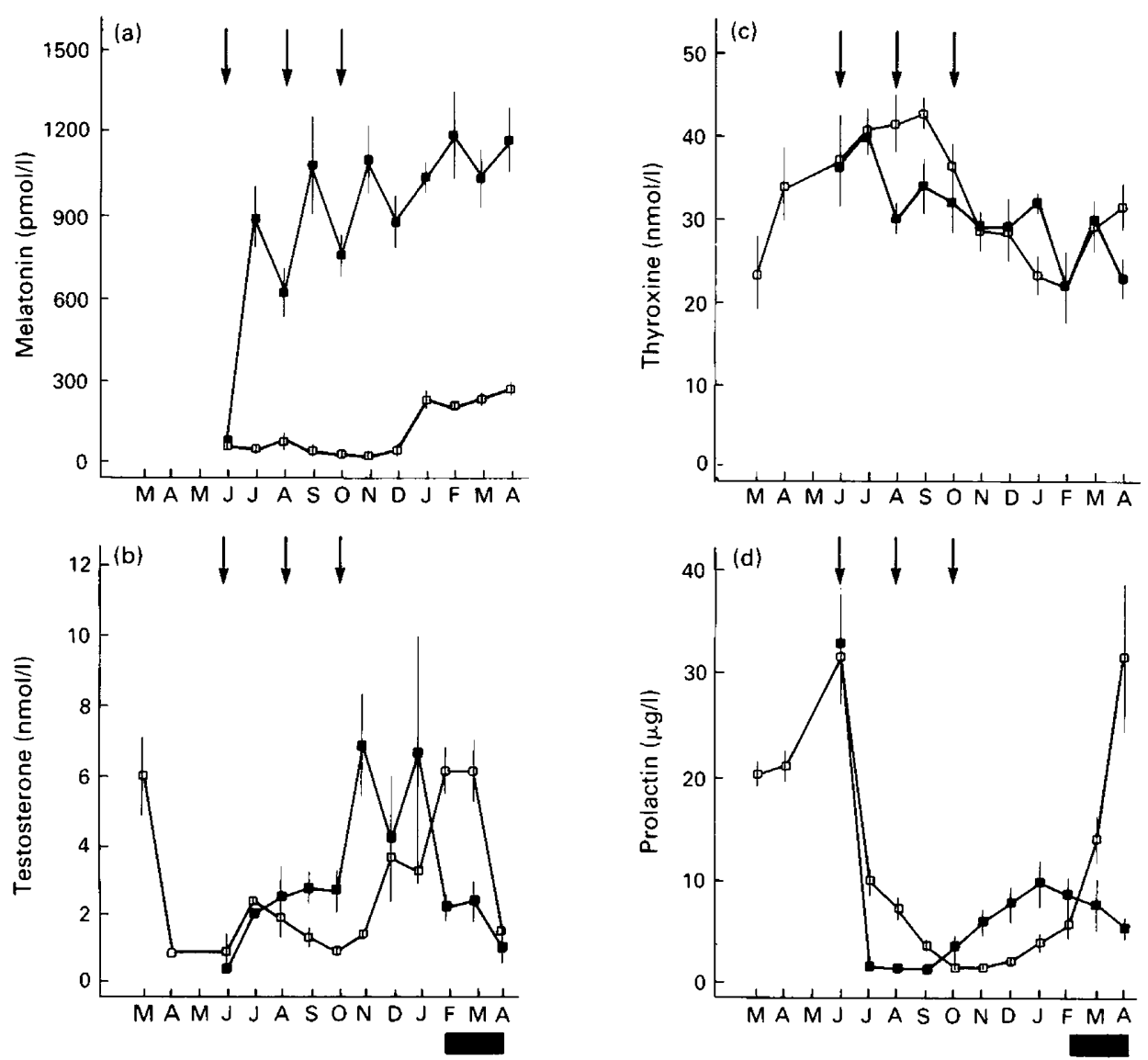

Fig. 1. Seasonal variations in (a) plasma melatonin, (b) testosterone, (c) thyroxine and (d) prolactin in a group of 5 foxes treated 3 times at 65-day intervals with melatonin implants (40 mg) from June until October 1987 ( $\square$ ) and in 5 untreated controls ( $\square$ ). The arrows in (a) depict the dates of melatonin administration and the horizontal bars the natural breeding season. Values are mean \pm s.e.m. 


\section{Testosterone}

The seasonal changes in plasma testosterone concentrations are depicted in Fig. 1(b). In the control animals plasma concentrations of testosterone decline significantly from March until April in 1987. Basal levels (0.3-2.4 nmol/1) were observed from April until November in 1987. Mean concentrations increased gradually from December 1987, reaching significant peak values ( $>6 \mathrm{nmol} / \mathrm{l}$ ) during the breeding season in February and March 1988, and then declining significantly to basal levels in April.

In the melatonin-treated males mean plasma concentrations of testosterone increased gradually from June to reach a peak concentration $(>6 \mathrm{nmol} / \mathrm{l})$ in November 1987 . Although there was great variation between males, concentrations remained high until January 1988 and then declined to basal levels in February 1988. Thereafter they remained low until the end of the study in April 1988. Peak values in November 1987 and January 1988 were significantly higher than values in June 1987 and April 1988.

In September, October and November 1987 plasma testosterone concentrations in melatonintreated males were significantly higher than in controls, whereas in February and March 1988 they were significantly lower.

\section{Thyroxine}

The seasonal changes in plasma thyroxine concentrations are shown in Fig. 1(c). In control animals thyroxine levels increased during spring and early summer 1987 to reach significant peak values $(>40 \mathrm{nmol} / \mathrm{l})$ in July, August and September. Values decreased gradually during the autumn and winter to a significant nadir $(<25 \mathrm{nmol} / \mathrm{l})$ in January and February 1988 before increasing again in March and April.

In the treated males thyroxine concentrations decreased between June and August 1987. During the rest of the study concentrations were variable. The lowest values were recorded in February and April 1988 ( <28 nmol/1). Mean plasma concentrations in June and July 1987 were significantly higher than in February and April 1988.

In August 1987 plasma thyroxine values were significantly lower in melatonin-treated males than in control animals.

\section{Prolactin}

The seasonal changes in plasma prolactin concentrations are shown in Fig. 1(d). In control animals the clearly marked annual prolactin cycle showed a maximum $(>30 \mu \mathrm{g} / 1)$ during spring/early summer and a minimum $(<1.5 \mu \mathrm{g} / \mathrm{l})$ during autumn/early winter.

In the melatonin-treated males plasma concentrations decreased significantly in June 1988 and remained low from July until September. Beginning in October, values gradually increased to a peak $(>9 \mu \mathrm{g} / \mathrm{l})$ in January 1988 and then declined until the end of the study in April.

From July until September 1987 and in April 1988 plasma concentrations of prolactin were significantly lower in melatonin-treated males than in control males. Between November 1987 and January 1988 values were significantly higher.

\section{Moulting cycle}

All treated males had completed the autumn moult and started to grow a winter coat when examined in August 1987, whereas control animals still had their summer coat.

\section{Discussion}

This study shows that administration of melatonin to silver fox males during long days influenced secretion of testosterone, prolactin and thyroxine in the same way as decreasing photoperiod does 
(Joffre \& Joffre, 1975; Joffre, 1976; Maurel \& Boissin, 1981; Maurel et al., 1984; Forsberg et al., 1989). These findings strengthen the hypothesis that melatonin is the hormonal signal transducing photoperiodic information in the silver fox, as described for other species.

The effects of constant exposure to high melatonin concentrations on the reproductive cycle result in an initial period of rapid testicular growth followed by involution (Forsberg et al., 1990), in the present study registered as a time shift in peak testosterone secretion.

Measurements of melatonin illustrated that the implants were capable of maintaining plasma levels at $600-1200 \mathrm{pmol} / \mathrm{l}$ during the experiment. However, it is not known whether these concentrations constitute supraphysiological levels, because the $24-\mathrm{h}$ endogenous melatonin profile in the silver fox has yet to be established. The treated and control animals showed strange melatonin patterns during the last 4 months of the study. A shift to higher levels was observed in untreated males. In the treated animals, in which a gradual decrease in melatonin concentrations had been expected after the implantation of melatonin in October, values remained high. We have no obvious explanation for the melatonin patterns observed during this period but the samples have been reassayed several times with the same result. They may reflect an increase in the endogenous secretion and/or a change in the metabolic clearance of the hormone. Such an increase or change would indicate that the constant supply of melatonin from the implants did not block the endogenous secretion of melatonin. Lack of inhibitory feedback effect of exogenous melatonin has been observed in the blue fox (A. J. Smith, personal communication) and the sheep (Kennaway, 1982; Lincoln \& Ebling, 1985).

In the present study melatonin was found to influence secretion of thyroxine and testosterone: thyroxine levels declined and testosterone levels increased during the period of testicular development. Maurel \& Boissin (1981) also reported a negative association between thyroxine and testosterone secretion in the red fox and suggested that interactions may occur between the annual reproductive and thyroid cycles. In the mink, thyroidectomy stimulated testosterone production and prolonged the period of testicular activity, indicating an inhibitory thyroid-gonadal interaction (Jacquet et al., 1986). Nicholls et al. (1988) suggested that thyroxine is essential in the process controlling reproductive quiescence in sheep and European starlings. There are also reports supporting the view that the pineal gland, via melatonin, has a modulatory effect on both gonadal and thyroid functions. Injections of melatonin for periods of 3-10 weeks reduced plasma thyroxine and TSH concentrations in hamsters, with the effects on gonadal and thyroid function being observed simultaneously (Vriend et al., 1979, 1982; Vriend, 1983). Creighton \& Rudeen (1988) observed that the effects of melatonin on the pituitary-gonadal and pituitary-thyroid axes were independently mediated via the central nervous system. In the hamster, however, the action of melatonin depends on its frequency and timing of administration; maintaining high levels of melatonin continuously by using high-dose injections or implants did not inhibit thyroxine or TSH production (Vriend et al., 1982; Vaughan et al., 1984).

In the present study, melatonin implants blocked the effects of long days, suppressed plasma prolactin concentrations and induced an earlier autumn moult. Experimental work in mink illustrates that a decrease in prolactin secretion plays a central role in controlling the autumn moult (Allain et al., 1981; Martinet et al., 1984; Rose et al., 1985, 1987). Likewise, depressed plasma concentrations of prolactin delay the spring moult in both mink and blue fox (Allain et al., 1981; Smith et al., 1987a, b), whereas prolactin injections induce an early spring moult in mink (Martinet et al., 1981).

Although the annual prolactin pattern shows clear correlations with the breeding season within a species, there is no such association between species. In the silver fox, blue fox and mink, prolactin rises during the breeding season (Martinet et al., 1981; Maurel et al., 1984; Smith et al., 1985), whereas in the sheep, goat, red deer and white-tailed deer it falls (Pelletier, 1973; Ravault, 1976; Mirarchi et al., 1978; Muduuli et al., 1979; Suttie et al., 1984). It therefore appears as if there is no fixed relationship between the timing of the breeding season and the seasonal prolactin cycle. Prolactin can therefore have a stimulatory or an inhibitory effect, depending on the species. The 
lack of synchrony may be related to different control systems for prolactin and gonadotrophic hormones. Prolactin secretion is under inhibitory control of the hypothalamus and is mainly mediated by dopamine (Nelson, 1987); in contrast, the stimulatory systems for LH and FSH are mediated by GnRH.

Although initially depressed, prolactin concentrations increased in the treated males and 'peaked' after 7 months of melatonin treatment. A similar pattern in prolactin secretion was observed in the ewe after melatonin treatment (Poulton et al., 1987). This 'peak' was followed by a rapid decrease in testosterone secretion. Prolactin is believed to modify the sensitivity of the hypothalamic-pituitary axis to testosterone feedback in rats and golden hamsters (McNeilly et al., 1978; Bartke et al., 1984; Matt et al., 1984). Smith et al. (1987c) and Mondain-Monval et al. (1988) observed a decline in LH concentrations in the blue fox when plasma concentrations of testosterone were maximal and prolactin was increasing. On the other hand, Worthy \& Haresign (1983) reported that seasonal anoestrus occurred in the absence of high levels of prolactin in ewes on a short-day lighting regimen. It is unclear whether the decline in testosterone in the treated males in this study reflects a prolactin-mediated change in sensitivity of the hypothalamic-pituitary system to the negative feedback effects of testosterone. If this is the case, then prolactin may be involved in regulating the normal breeding season in this species.

Since TRH releases prolactin as well as TSH, it is also possible that thyroxine is involved in prolactin regulation through changes in hypothalamic sensitivity to thyroxine feedback (De Léan et al., 1977; Vriend \& Ralcewicz, 1987). Ottenweller \& Hedge (1981) reported that thyroid hormones altered the daily patterns of plasma prolactin in rats. Jacquet et al. (1986) observed that thyroidectomy did not modify the general pattern of prolactin secretion in the mink, but prolactin secretion was enhanced by increasing daylength in the absence of thyroid hormones. Although major changes in prolactin secretion occur in silver fox males under natural daylight conditions and after melatonin administration, a relationship between these changes and thyroxine has yet to be established.

We thank Dr G. D. Niswender for the melatonin antiserum.

\section{References}

Allain, D., Martinet, L. \& Rougeot, J. (1981) Effect of melatonin implants on changes in the coat, plasma prolactin and testis cycle in the mink (Mustela vison). In Photoperiodism and Reproduction in Vertebrates, pp. 263-271. Eds R. Ortavant, J. Pelletier \& J.-P. Ravault. INRA Services Publications, Versailles.

Arendt, J. (1986) Role of the pineal gland and melatonin in seasonal reproductive function in mammals. Oxford Rev. Reprod. Biol. 8, 266-320.

Bartke, A., Matt, K.S., Siler-Khodr, T.M., Soares, M.J., Talamantes, F., Goldman, B.D., Hogan, M.P. \& Hebert, A. (1984) Does prolactin modify testosterone feedback in the hamster? Pituitary grafts alter the ability of testosterone to suppress luteinizing hormone and follicle-stimulating hormone release in castrated male hamsters. Endocrinology 115, 1506-1510.

Connor, M.L. (1988) Melatonin as a furring enhancer: Effects on growth rate, feed consumption and reproduction in the silver fox. In Biology, Pathology and Genetics of Fur Bearing Animals, pp. 437-443. Eds B. D. Murphy \& D. B. Hunter. Canada Milk Breeders Association, Rexdale.

Creighton, J.A. \& Rudeen, P.K. (1988) Effects of melatonin and thyroxine treatment on reproductive organs and thyroid hormone levels in male hamsters. J. Reprod. Fert., Abstr. Ser. 1, Abstr. 84.
De Léan, A., Garon, M., Kelly, P.A. \& Labrie, F. (1977) Changes of pituitary thyroid releasing hormone (TRH) receptor level and prolactin response to TRH during the rat estrous cycle. Endocrinology 100, $1505-1510$.

Forsberg, M., Fougner, J.A., Hofmo, P.O., Madej, M. \& Einarsson, E.J. (1989) Photoperiodic regulation of reproduction in the male silver fox (Vulpes vulpes). $J$. Reprod. Fert. 87, 115-123.

Forsherg, M., Fougner, J.A., Hofmo, P.O. \& Einarsson, E.J. (1990) Effect of melatonin implants on reproduction in the male silver fox (Vulpes vulpes). $J$. Reprod. Fert. 88, 383-388.

Greenwood, F.G., Hunter, W.H. \& Glover, J.S. (1963) The preparation of ${ }^{131}$ I-labelled human growth hormone of high specific radioactivity. Biochem. J. 89, $114-123$.

Jacquet, J.-M., Coutant, C., Maurel, D., Boissin-Agasse, L. \& Boissin, J. (1986) Influence de la thyroïdectomie sur les variations, au cours du printemps et de l'été, de l'activité testiculaire et de la prolactinémie chez le Vison. C. r. hebd. Séanc. Acad. Sci. Paris D 303, $367-370$.

Joffre, M. (1976) Puberté et cycle génital saisonnier du renard mâle (Vulpes vulpes). Annls Biol. anim. Biochim. Biophys. 16, 503-520. 
Joffre, M. \& Joffre, J. (1975) Variation de la testostéronémie au cours de la période prépubère du Renardeau et au cours du cycle génital saisonnier du Renard mâle adulte (Vulpes vulpes) en captivité. C. r. hebd. Séanc. Acad. Sci. Paris D 281, 819-821.

Kennaway, D.J., Gilmore, T.A. \& Seamark, R.F. (1982) Effect of melatonin implants on the circadian rhythm of plasma melatonin and prolactin in sheep. Endocrinology 110, 2187-2188.

Larsson, M. \& Lumsden, J.H. (1980) Evaluation of an enzyme linked immunosorbent assay (ELISA) for determination of plasma thyroxine in dogs. Zentbl. VetMed. 27, 9-15.

Lincoln, G.A. \& Ebling, F.J.P. (1985) Effect of constant release implants of melatonin on seasonal cycles in reproduction, prolactin secretion and moulting in rams. J. Reprod. Fert. 73, 241-253.

Martinet, L., Meunier, M. \& Allain, D. (1981) Control of delayed implantation and onset of spring moult in the mink (Mustela vison) by daylight ratio, prolactin and melatonin. In Photoperiodism and Reproduction, pp. 253-261. Eds R. Ortavant, J. Pelletier \& J.-P. Ravault. INRA Services Publications, Versailles.

Martinet, L., Allain, D. \& Weiner, C. (1984) Role of prolactin in the photoperiodic control of moulting in the mink (Mustela vison). J. Endocr. 103, 9-15.

Matt, K.S., Bartke, A., Soares, M.J., Talamantes, F., Hebert, A. \& Hogan, M.P. (1984) Does prolactin modify testosterone feedback in hamster? Suppression of plasma prolactin inhibits photoperiod-induced decreases in testosterone feedback sensitivity. Endocrinology 115, 2098-2103.

Matthews, M.J., Benson, B. \& Richardson, D.L. (1978) Partial maintenance of testes and accessory organs in blinded hamsters by homoplastic anterior pituitary grafts or exogenous prolactin. Life Sci. 23, $1131-1137$.

Maurel, D. \& Boissin, J. (1981) Plasma thyroxine and testosterone levels in the red fox (Vulpes vulpes L.) during the annual cycle. Gen. comp. Endocrinol. 43, 402-404.

Maurel, D., Lacroix, A. \& Boissin, J. (1984) Seasonal reproductive endocrine profiles in two wild animals: the red fox (Vulpes vulpes) and the European badger (Meles meles L.) considered as short day mammals. Acta endocr., Copenh. 105, 130-138.

McNeilly, A.S., Sharpe, R.M., Davidson, D.W. \& Fraser, H.M. (1978) Inhibition of gonadotrophin secretion by induced hyperprolactinaemia in the male rat. $J$. Endocr. 79, 59-68.

Mirarchi, R.E., Howland, B.E., Scanlon, P.F., Kirkpatrick, R.L. \& Sanford, L.M. (1978) Seasonal variation in plasma $\mathrm{LH}$, prolactin and testosterone concentrations in adult male white-tailed deer. Can.J. Zool. 56, 121-127.

Mondain-Monval, M., Smith, A.J., Simon, P., Möller, O.M., Scholler, R. \& McNeilly, A.S. (1988) Effect of melatonin implantation of the seasonal variation of FSH secretion in the male blue fox (Alopex lagopus). J. Reprod. Fert. 83, 345-354.

Muduuli, D.S., Sanford, L.M., Palmer, W.M. \& Howland, B.E. (1979) Secretory patterns and seasonal changes in LH, FSH, prolactin and testosterone in the male pygmy goat. J. Anim. Sci. 49, 543-553.
Nelson, E.L. (1987) Hypothalamic regulation of anterior pituitary function. In Handbook of Endocrinology, Volume II, Part B, pp. 1-21. Eds G. H. Gass \& H. M. Kaplan. CRC Press Inc., Boca Raton.

Nicholls, T.J., Follett, B.K., Goldsmith, A.R. \& Pearson, H. (1988) Possible homologies between photorefractoriness in sheep and birds: the effect of thyroidectomy on the length of the ewe's breeding season. Reprod. Nutr. Dévelop. 28 (2B), 375-385.

Ottenweller, J.E. \& Hedge, G.A. (1981) Thyroid hormones are required for daily rhythms of plasma corticosterone and prolactin concentration. Life Sci. $\mathbf{2 8}$, 1033-1040.

Pelletier, J. (1973) Evidence for photoperiodic control of prolactin release in rams. J. Reprod. Fert. 35, 143-147.

Poulton, A.L., English, J., Symons, A.M. \& Arendt, J. (1987) Changes in plasma concentration of $\mathrm{LH}$, FSH and prolactin in ewes receiving melatonin and short-photoperiod treatments to induce early onset of breeding activity. J. Endocr. 112, 103-111.

Ravault, J.-P. (1976) Prolactin in the ram: seasonal variation in the concentration of blood plasma from birth to three years old. Acta endocr., Copenh. 83, 720-725.

Reiter, R.J. (1987) Mechanisms of control of reproductive physiology by the pineal gland and its hormones. In Advances in Pineal Research, pp. 109-125. Eds R. J. Reiter \& F. Fraschini. John Libbey \& Co. Ltd, London.

Rose, J., Stormshak, F., Oldfield, J. \& Adair, J. (1985) The effects of photoperiod and melatonin on serum prolactin levels of mink during the autumn moult. $J$. Pineal Res. 2, 13-19.

Rose, J., Oldfield, J. \& Stormshak, F. (1987) Apparent role of melatonin and prolactin in initiating winter fur growth in mink. Gen. comp. Endocr. 65, 212-215.

Smith, A.J., Mondain-Monval, M., Möller, O.M., Scholler, R. \& Hansson, V. (1985) Seasonal variations of LH, prolactin, androstenedione, testosterone and testicular FSH binding in the blue fox (Alopex lagopus). J. Reprod. Fert. 74, 449-458.

Smith, A.J., Mondain-Monval, M., Andersen Berg, K., Simon, P., Forsberg, M., Clausen, O.P.F., Hansen, T., Möller, O.M. \& Scholler, R. (1987a) Effects of melatonin implantation on spermatogenesis, the moulting cycle and plasma concentrations of melatonin, $\mathrm{LH}$, prolactin and testosterone in the male blue fox (Alopex lagopus). J. Reprod. Fert. 79, 379-390.

Smith, A.J., Mondain-Monval, M., Simon, P., Andersen Berg, K., Clausen, O.P.F., Hofmo, P.O. \& Scholler, R. (1987b) Preliminary studies of the effects of bromocriptine on testicular regression and the spring moult in a seasonal breeder, the male blue fox (Alopex lagopus). J. Reprod. Fert. 81, 517-524.

Smith, A.J., Mondain-Monval, M., Andersen Berg, K., Gordeladze, J.O., Clausen, O.P.F., Simon, P. \& Scholler, R. (1987c) Sexual development in the immature male blue fox (Alopex lagopus), investigated by testicular histology, DNA flow cytometry and measurement of plasma FSH, LH, testosterone and soluble testicular MN2 + -dependent adenylate cyclase activity. J. Reprod. Fert. 81, 505-515.

Steger, R.W., Reiter, R.J. \& Siler-Khodr, T.M. (1984) Interactions of pinealectomy and short-photoperiod 
exposure on the neuroendocrine axis of the male Syrian hamster. Neuroendocrinology 38, 158-163.

Suttie, J.M., Lincoln, G.A. \& Kay, R.N.B. (1984) The endocrine control of antler growth in red deer stags. J. Reprod. Fert. 71, 7-15.

Vaughan, M.K., Richardson, B.A., Petterborg, L.J., Holtorf, A.P., Vaughan, G.M., Champney, T.H. \& Reiter, R.J. (1984) Effects of injections and/or chronic implants with melatonin and 5-methoxytryptamine on plasma thyroid hormones in male and female Syrian hamsters. Neuroendocrinology 39, 361-366.

Vriend, J. (1983) Evidence for pineal gland modulation of the neuroendocrine-thyroid axis. Neuroendocrinology 36, 68-78.

Vriend, J. \& Ralcewicz, T. (1987) Introduction to the pineal gland. In Handbook of Endocrinology, Volume II, Part A, pp. 1-30. Eds G. H. Gass \& H. M. Kaplan. CRC Press Inc., Boca Raton.
Vriend, J., Reiter, R.J. \& Anderson, G.R. (1979) Effects of the pineal and melatonin on thyroid activity of the male golden hamster. Gen. comp. Endocr. 38, 189-195.

Vriend, J., Richardson, B., Vaughan, M.K., Johnson, L.Y. \& Reiter, R.J. (1982) Effects of melatonin on thyroid physiology of female hamsters. Neuroendocrinology $35,79-85$.

Worthy, K. \& Haresign, W. (1983) Evidence that the onset of seasonal anoestrus in the ewe may be independent of increasing prolactin concentrations and day length. J. Reprod. Fert. 69, 41-48.

Zipf, W.B., Payne, A.H. \& Kelch, R.P. (1978) Prolactin, growth hormone, and luteinizing hormone in the maintenance of testicular luteinizing hormone receptors. Endocrinology 103, 595-600.

Received 23 October 1989 